\title{
POLD1 wt Allele
}

National Cancer Institute

\section{Source}

National Cancer Institute. POLD1 wt Allele. NCI Thesaurus. Code C106225.

Human POLD1 wild-type allele is located in the vicinity of $19 q 13.3$ and is approximately 34 $\mathrm{kb}$ in length. This allele, which encodes DNA polymerase delta catalytic subunit protein, plays a role in DNA replication. Mutation of the gene may be associated with increased susceptibility to colorectal malignancies. 